\title{
Obituaries
}

\section{Frank Pantridge}

Cardiologist who created pre-hospital coronary care through the invention of the portable defibrillator

Frank Pantridge invented the portable defibrillator. The first model operated from car batteries and weighed $70 \mathrm{~kg}$. Descendants of that clumsy contraption-created in 1965 when Frank was a consultant physician at the Royal Victoria Infirmary in Belfast and produced with technician Alfred Mawhinney and senior house officer John Geddes-are now used a countless number of times daily throughout the world saving an incalculable number of lives annually. Frank installed the "portable" defibrillator in an ambulance, thus creating pre-hospital coronary care.

Frank's concepts were rapidly adopted in the United States and elsewhere. An exception was the United Kingdom, although an editorial in the Lancet in 1967 stated that Pantridge and Geddes had revolutionised emergency medicine.

The portable defibrillator was a response to the epidemic proportions that coronary heart disease had reached by the 1950s. In the early 1960s hospital care units appeared in North America. Frank Pantridge doubted their value since epidemiological data had shown that the majority of coronary deaths occurred suddenly outside hospital. It was known that most coronary deaths resulted from ventricular defibrillation. Frank postulated that if the problem lay outside hospital, ventricular defibrillation should be corrected where it occurred. However, correction required a defibrillator and the machines available operated only in hospital from the mains electricity supply.

James Francis Pantridge was born on the outskirts of the historic village of Hillsborough, northern Ireland, in 1916. He qualified at Queen's University, Belfast, in 1939, and on the declaration of the second world war he immediately reported to the recruiting office, there being no conscription in Northern Ireland. Posted to the Far East he became medical officer of an infantry battalion. During the battle that preceded the fall of Singapore, he was given an immediate award of the Military Cross. The citation read, "This officer worked unceasingly under the most adverse conditions of continuous bombing and shelling and was an inspiring example to all with whom he came in contact. He was absolutely

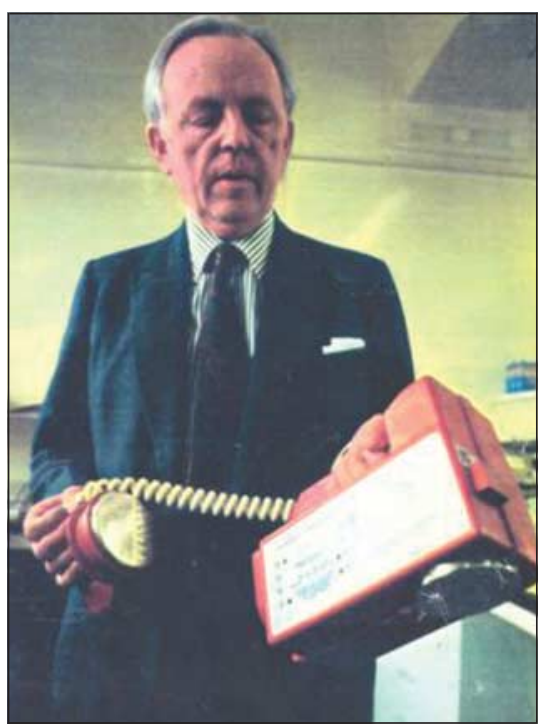

While Frank supported cardiopulmonary resuscitation (CPR) he was well aware of its limitations. He knew that the longer ventricular fibrillation was present the less likely long term survival would result from its removal. The aim, he preached, should be immediate correction of ventricular fibrillation. He maintained that any lay individual who could do CPR was capable of using a defibrillator. A defibrillator should be beside every fire extinguisher since, Frank said, life was more important than property. Harnessing a miniature capacitor manufactured for NASA he designed a defibrillator weighing only $3 \mathrm{~kg}$.

It was argued that a defibrillator in the hands of a lay individual might be used when unnecessary. The citizen who had fainted or was drunk might be given a potentially dangerous shock. Thus, Frank suggested that the miniature defibrillator should incorporate a fail-safe mechanism like a gun's safety catch. This would ensure that the instrument would not deliver a shock unless ventricular fibrillation was present

The defibrillator for implantation in the cool under the heaviest fire and completely regardless of his own personal safety at all times."

Captured at the fall of Singapore, he spent much of his captivity in the slave labour camps on the Siam-Burma Railway, including some months in the notorious "death" camp Tanbaya, on the Siam-Burma border. He survived the usually fatal cardiac beriberi, an experience that may have initiated a special interest in heart disease. The fall of Singapore, the impregnable fortress, left its mark. He was to say that never again would he have any confidence in those in control of affairs.

Back in Belfast at the end of 1945, the only appointment he could obtain was that of part time supernumerary lecturer in the Queen's University's department of pathology. However, he obtained a scholarship to the United States, where, at the University of Michigan, he worked with F N Wilson, then the world authority on electrocardiography.

He returned to Belfast in 1950 and was appointed physician at the Royal Victoria Hospital. He quickly established an internationally acclaimed cardiology unit, recognised not only in the erudite medical journals but also in the North American lay press. chest developed by Michel Mirowski in Baltimore had just such characteristics. Frank thought that a similar circuit should operate from the chest surface. He discussed this with Mirowski, who was adamant that it was impossible. Frank persisted and eventually the automatic external defibrillator emerged.

Frank had a veneer of arrogance at times but this often concealed an innate shyness. On a good day he looked as though he owned the world, on a bad day he looked as though he didn't care who owned it. He appreciated being stood up to, but this, in truth, was often hard to do. He was a man with staccato delivery and a quickness of wit, which often bore the Irish element of visual humour; the clicked fingers acted as punctuation and the stiff index finger directed the verbal missile.

He never married. [Alun Evans]

James Francis Pantridge, cardiologist Belfast (b 1916; q Queen's University, Belfast, 1939; CBE, MD, FRCP, FACC), d 26 December 2004.

Longer versions of these obituaries are available on bmj.com 


\section{Herbert Erik Reiss}

A pioneer of amniocentesis and laparoscopic wedge resection

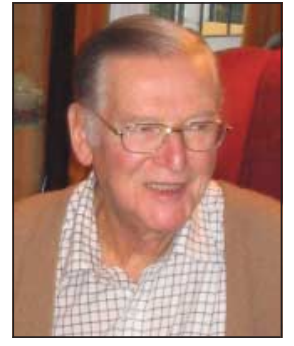

Not only did Herbert Reiss transform a somewhat rundown obstetric department into a first class unit renowned for its teaching of midwives, medical students, and postgraduates, but he also made substantial contributions to the treatment of cervical incompetence and helped in pioneering amniocentesis and laparoscopic ovarian wedge resection.

Of Danish and German Jewish origin, the Reiss family came to England in 1934. Herbert attended Bradford Grammar School and, having been told by a teacher that he would never speak English properly, proceeded, in his characteristic driven fashion, to win a school prize in English and

\section{Dorothy Joan Mary (“Joan”) Baker}

General practitioner Walsall 1948-79 (b Sheffield 1921; q Birmingham 1942), d 29 February 2004.

After a house job at Queen Elizabeth Hospital, Birmingham, she went into general practice in Walsall, working part time while the mother of three young children. Latterly she went into partnership with her late husband, Mac Baker, before retiring because of ill health to the countryside around Tenbury Wells to pursue an active interest in rural architecture. She leaves three children and one grandchild. [ANDREW BAKER]

\section{Keith Arthur Moore}

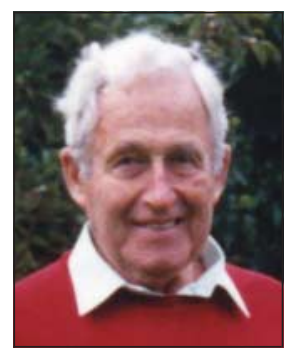

Consultant surgeon North Middlesex Hospital, London, 1951-76 (b 1911; q Sydney 1935; FRCS 1940), d 6 January 2005. a classics scholarship to Oxford. Rejected from the call up on account of his foreign origin, he switched to the study of medicine and, while a medical student, sat in on the Nuremberg trials as the leader of an international student delegation.

After naturalisation he served in the Royal Army Medical Corps (1950-2) in Hong Kong and Malaysia. He was lecturer in obstetrics and gynaecology at University College Hospital in 1956-7 and senior lecturer in Hong Kong in 1958-9.

In 1959 he became consultant obstetrician and gynaecologist at Hackney Hospital, London. His chief interest was female infertility and repeated miscarriage, and in the early days of our knowledge about cervical incompetence he got the Indian obstetrician and gynaecologist Professor V N Shirodkar to demonstrate his cervical suture at Hackney Hospital. Later at Hackney he was among the pioneers of amniocentesis for the diagnosis of Down's syndrome. He also played an important part in introducing laparoscopic wedge resection for polycystic ovarian disease.

He was a dominant and prominent founding member of the British Fertility
Society (BFS), which is now a multidisciplinary organisation of national importance. He became BFS's second chairman in 1986 , when he was also president of the section of obstetrics and gynaecology of the Royal Society of Medicine.

Resigning from the NHS in 1979 in protest against the closure of the thriving and large Hackney Hospital obstetric unit, he continued in private practice until 1990 . He wrote numerous papers, mainly on female infertility, and edited a dictionary of reproductive medicine in 1998 (Reproductive Medicine: From A-Z), which was translated into Italian.

Herbert was a bon viveur who loved fast cars, foreign travel, fine wines, mountain air, and genial company. He demonstrated his iron will (and stubbornness) by skiing long after his doctors advised him not to do so.

Predeceased by his wife, Ann, he leaves two children. [FRANK LOEFFLER]

Herbert Erik Reiss, consultant obstetrician and gynaecologist Hackney Hospital, London, 1959-79 (b Hamburg 1922; Oxford/UCH 1948; FRCOG 1967), died from heart disease on 11 February 2005.
Keith came to England to work for his FRCS. A year later he joined the Royal Army Medical Corps and served in the Middle East before the fall of Tobruk. He subsequently escaped from an Italian prisoner-of-war camp and rejoined the advancing Allied forces. In 1946 he returned to Australia, but was unhappy with the ethos of private practice in Brisbane and so returned to England and soon obtained his consultant post. Much of his retirement was spent fulfilling his lifelong ambition to restore an old mill. In his later years he had rapidly increasing glaucoma-related blindness. He leaves a wife, Sally, and four children. [RAYMOND HuRT]

\section{William Douglas Park}

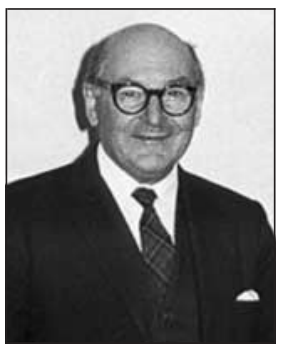

Former consultant general surgeon Oldchurch Hospital, Romford, and King George's Hospital, Ilford (b Melbourne, Australia, 1912; q King's College London/St Bartholomew's Hospital 1935; FRCS, MS, SJM), died from bronchopneumonia on 24 August 2004.
William came to Britain in 1924. During the second world war he worked as a specialist in emergency surgery. He subsequently moved to Connaught Hospital, Walthamstow, where he was honorary orthopaedic surgeon. Throughout his career he had interests in orthopaedic, upper gastrointestinal, and cardiac surgery. He was a superb woodcarver, and was commissioned to make a matching pair of crested clocks for the Royal College of Surgeons' committee room. Predeceased by his wife, Pat, he leaves two daughters and five grandchildren. [Richard Pertwee]

\section{Jan Pollert}

Former consultant chest physician south London (b Czechoslovakia 1914; q Prague 1939), died from left ventricular failure on 9 November 2004. Jan was a Czechoslovakian Jew. His family suffered under Nazism and communism, and almost all perished. He reached Palestine, joining the Czech army and then the Royal Army Medical Corps, and while serving he developed pulmonary tuberculosis. This determined his choice of specialty. A relapse of his disease necessitated the very chemotherapy he had helped to establish at Grove Park, then the only British hospital to use the vile tasting para amino salicylic acid. After retirement Jan survived a haemopericardium following a bypass. He leaves his second wife, Trudy; two daughters; and five grandchildren. [BERYL TURNER, MARY FARQUHARSON] 